Article

\title{
Linking Environmental Regulation and Financial Performance: The Mediating Role of Green Dynamic Capability and Sustainable Innovation
}

\author{
Xinpeng Xing ${ }^{1}{ }^{(0)}$, Tiansen Liu ${ }^{2,3}$, Lin Shen ${ }^{1}$ and Jianhua Wang ${ }^{1, *}$ \\ 1 School of Business, Jiangnan University, Wuxi 214122, China; xinpeng@jiangnan.edu.cn (X.X.); \\ 8201609118@jiangnan.edu.cn (L.S.) \\ 2 School of Economics and Management, Harbin Engineering University, Harbin 150001, China; \\ tiansen0328@hrbeu.edu.cn \\ 3 School of Social and Behavioral Sciences, Nanjing University, Nanjing 210023, China \\ * Correspondence: jianhua.w@jiangnan.edu.cn; Tel.: +86-182-5154-9736
}

Received: 16 December 2019; Accepted: 21 January 2020; Published: 31 January 2020

\begin{abstract}
This study develops a multiple mediating model for exploring the link between environmental regulation and financial performance through green dynamic capability, sustainability exploration/exploitation innovation, based on the data from 355 Chinese manufacturing firms. Empirical results support a mediating role of green dynamic capability and sustainability exploration/exploitation in the link between environmental regulation and financial performance, respectively. What's more, our findings indicate that environmental regulation can help improve financial performance via two multiple mediating paths, i.e., green dynamic capability and sustainability exploration innovation, as well as green dynamic capability and sustainability exploitation innovation. These key findings will help to understand how important green dynamic capability and sustainable innovation is when Chinese manufacturing firms establish a business-politics tie.
\end{abstract}

Keywords: environmental regulation; green dynamic capability; sustainability exploration innovation; sustainability exploitation innovation; financial performance

\section{Introduction}

Climate change and environmental pollution have become inevitable problems in the pursuit of economic growth [1,2]. In this context, sustainable development is viewed as a key way to mitigate the pressure caused by economic development and environmental protection, and requires the joint efforts from multi-stakeholders, including government, business organization, and public [3,4]. As a feasible approach for government to normalize environmental behaviors of economic participants, environmental regulation plays an increasingly important role in decreasing the negative effect of firms' operations process on the natural environment $[5,6]$. At the same time, technology innovation that can be viewed as a key driver of economic growth is also responsible for balancing economic development and environmental protection [7-9]. Therefore, it is a key to identify the link among environmental regulation, technology innovation, and economic output, thus designing more paths for firms' sustainable development.

To reveal this link, quite a lot of literature has emerged with a typical research finding as the Porter Hypothesis [10]. The early view in terms of economic growth and environmental protection argued that strict environmental regulations require firms to increase investment in environmental protection and green technology innovation [11]. Nevertheless, the rise in the compliance cost effect caused by environmental regulation is bound to decrease financial performance [12]. The Porter 
Hypothesis posits that reasonably designing environmental policies can motivate innovation and productivity gains, partially/fully offset compliance cost, and even generate net benefits [13,14]. This may improve financial performance through creating absolute advantage, which mainly comes from "innovation advantage" and "first-mover advantage" [15]. However, there still exist some conflicts on how governments develop policy regulation that can improve the comprehensive performance of firms $[2,16,17]$. The empirical results of $[16,18]$ illustrated that environmental regulation is usually negatively linked with financial performance, while by contrast, some studies suggested designing the environmental regulation that will not only lead the cost-saving innovation that can compensate for the compliance cost, but also help firms to gain low-cost and differential competitive edges, thereby improving financial performance $[13,19,20]$. However, the finding of $[21,22]$ argued that environmental regulation positively affects firms' financial performance, thus verifying their fluctuating links.

The inconsistency between environmental regulation and financial performance has attracted a focus from subsequent research, and their transmission mechanism has been also characterized from multi-perspectives [23,24]. From the perspective of subdivision of environmental regulations, some research focused on such regulation from the aspects of administrative orders and market incentives. For instance, results of [20] presented that market incentives can help improve financial performance, but [25] indicated that this incentive has a negative effect. While on the whole, prior research held the same view that there is no significant relationship between command-controlled environmental regulation and financial performance.

From the perspective of segmented technology innovation, the effect of environmental regulation on economic output via technology innovation was explored [26,27]. For instance, [22] found that environmental commitment and sustainability exploitation innovation significantly mediate the link of environmental regulation and financial performance, while sustainability exploration innovation cannot motivate the effect of this regulation on financial performance. Additionally, this regulation can also positively affect financial performance through voluntary efficiency-oriented innovations, while it is not applicable to the regulation-oriented innovation. What's more, some literature suggested that internal organizational factors, e.g., CSR-contingent executive compensation, dynamic capability, slack resources, and strategy design, need to be considered in the "strong" Porter Hypothesis [28-31]. However, only a few literature incorporated internal factors of organizations into the research framework in terms of linking these three variables.

Overall, there are still two gaps in existing literature. First, the effect of existing environmental regulation on financial performance through technology innovation is controversial, and it needs to subdivide the specific type of environmental regulation and technology innovation $[23,32]$. Second, it needs to identify what are key internal factors that can lead the transmission mechanism of environmental regulation, sustainable dual-innovation, and financial performance $[24,33]$. In order to fill in these two gaps, this study will incorporate both green dynamic capability and sustainable innovation into the Porter Hypothesis framework, and then explore the potential path from environmental regulation to financial performance through green dynamic capability and sustainable innovation.

To fill the research gaps in the existing literature, our study aims to provide insights into the implementation path of the strong Porter Hypothesis by exploring the meditating effect of green dynamic capability and sustainability exploration/exploitation innovation in linking environmental regulation and financial performance. Specifically, this study extends the understanding of the relationship between environmental regulation, sustainable innovation, and firm performance by dividing sustainable innovation into sustainability exploration innovation and sustainability exploitation innovation. Furthermore, this study strives to new insights into the link between environmental regulation and financial performance by inserting green dynamic capability into the conceptual framework of Porter Hypothesis. Meanwhile, this study tries to add empirical evidence for the theoretical framework, proposed by prior studies [33], which emphasizes the importance of internal capability and sustainable innovation for the Porter Hypothesis. Overall, we expect to provide a better understanding of strong Porter Hypothesis by answering how firms establish green 
capability, and then develop sustainable innovation mode to improve economic growth in the specific environmental regulation.

The rest of this study is structured as follows. Section 2 organizes a theoretical analysis and then develops our research hypotheses. Section 3 introduces data collection and research methodology. Section 4 presents the key empirical results. Section 5 further discusses our key findings and thus proposes research implications. Section 6 concludes this study and presents our research limitations and future research.

\section{Theoretical Underpinnings and Hypotheses Development}

\subsection{Environmental Regulation}

Enlightened by the Resource-based View, maximizing the value of resources is the key to create competitive edges of firms or industries [25]. Accordingly, there are two sides about environmental regulation that can be discussed as follows. On the one hand, environmental policy may restrict the circulation of resources in the markets or inter-firms, thus resulting in the lack of resources. On the other hand, limiting the use of materials in production process will make firms explore innovative production modes, and thus enhance the competitive edges in terms of innovation aspects. This is similar to the Innovation Compensation Effect proposed by Porter. Based on the Porter Hypothesis, environmental regulation is not only a policy tool for protecting the natural environment, but also an arguable facet to promote firms' innovation practices. However, there still exists a considerable debate in terms of the efficiency and internal transmission mechanism of environmental regulation $[16,18]$. In view of the existence of environmental total factor productivity that was proposed in recent years, different types of environmental regulations have different influence on such productivity in different industrial sectors [23].

Therefore, researchers are committed to reveal the effect of different regulations on sustainable operations. Enlightened by the "narrow" Porter Hypothesis, some research divided environmental regulation into mandatory regulation and voluntary regulation, and drew the effect of these two on firms' performance levels [20,34]. Then [35] divided it into three aspects, i.e., command-controlled regulation, voluntary regulation, and market-oriented regulation. These regulations require firms to increase environmental management investment that aims to consolidate the technology innovation that will help environmental protection.

The interaction among environmental regulation, internal factors, sustainable innovation, and financial performance needs to be systematically explored. Among them, environmental regulation, as the starting point of Porter Hypothesis, is considered to be the key part of theoretical framework. Although a large number of studies analyzed the theoretical path from environmental regulation to firms' performance via technology innovation, few of them involved how to select an efficient path for both government and firms. Further, prior studies less focused on the inter-firms' factors in the research framework, e.g., operational capability, management attitudes, and strategic positions, which are affected by external policy tools [16]. Therefore, in order to find an efficient way to address these problems, we aim to analyze the internal and external effects that environmental regulation put on financial performance.

\subsection{Green Dynamic Capability}

Dynamic capability was defined as a kind of process in terms of firms' resources use, especially focusing on the process of rearranging or reconfiguring resources, and this process emphasizes how firms use the limited resources to adapt to market environments [36]. Subsequent studies proposed various views about it in terms of organization internality and effectiveness of resource use. [37] emphasized the integration of knowledge and technology resources of dynamic capability, and argued that this capability can be portrayed as a series of combine capabilities that promote firms to create knowledge. 
From the economic perspective, some prior studies [38,39] viewed dynamic capability as a kind of organizational guideline that is represented by managers' capability to integrate opportunities to achieve high financial performance and establish firms' competitive edge. With the further research of dynamic capability in firms' sustainable innovation and high-quality development, [40] proposed the view of "green development" into the theory system of dynamic capability, and put forward the concept of green dynamic capability. It was interpreted as the capability of firms to develop their green organizational capability to respond to market changes by using existing resources and a range of knowledge renewal activities. This study takes the influence path of green dynamic capability as the internal factors in the organizations.

However, the literature about green dynamic capability tends to focus on a certain aspect about firm sustainability. For instance, [41] explored the positive internal mediating role of dynamic capability (sensing, seizing, and reconfiguring) and innovation towards firms' sustainability. [42] developed a framework of how dynamic capability works in the business network. What's more, [43] investigated how green dynamic capability improves the competitive edges from the green development perspective. Furthermore, few researches regarded green dynamic capability as the mediating role in the model of strong view of Porter Hypothesis. Therefore, to fulfill this gap, we explore the functions of green dynamic capability in the multiple paths involving environmental and economic factors to reinforce the researches related to the Porter Hypothesis.

\subsection{Sustainability Exploitation/Exploration Innovation}

Sustainable innovation was defined by $[44,45]$ as innovation which has enabled firms to improve their financial performance while reducing negative environmental and social impacts. In the view of [46], sustainable practices are essential to firms' further development. And the reasons why firms perform innovation activities involve two aspects: For one thing, firms with high innovative capability are likely to tackle with dynamic environment problems; for another, individual or organizational innovation to obtain competitive edges.

To explore the effect of different types of sustainable innovation, the definition of sustainability exploitation innovation and sustainability exploration innovation conceptually was proposed by [47]. Sustainability exploitation innovation illustrates that organizational on-going incremental improvements are essential to tackle with the scarcity of resources, e.g., appropriate mechanism to resources reduction and renting rules to other firms [47,48]. In contrast, sustainability exploration innovation focuses on reducing environmental costs by enhancing exploration innovation activities, and it is designed to achieve business sustainability, future prosperity, and competitive edges [49]. At the same time, by analyzing the impact of green innovation in Taiwan's manufacturing industry in China, [50] concluded that green innovation will create competitive edges to manufacturing firms, of which green product innovation played the most important effect.

In the Instrumental Stakeholder Theory, organizations need to give the priority of shareholders' influence on sustainable development. It emphasizes that managing the link with shareholders smoothly when operating innovative practices contributes to significant improvement of financial performance. What's more, [51] found that organizations strive to gain competitive edges through sustainability exploitation innovation by successfully addressing stakeholder expectations. But the Sustainability-oriented Theory presents the initiatives of organizations when they confront with changing markets. It means that their purposes to make innovation are not only the pressure from government and shareholders, but also from their commitment to sustainable economic success [49]. Accordingly, establishing a conceptual model on exploitation/exploration innovation towards economic performance is necessary for practical improvement.

However, only a few studies involving sustainability exploitation innovation and sustainability exploration innovation function in a conceptual model, which contains both internal and external factors, e.g., organizational leadership and green dynamic capability. Hence, this study concentrates on firms' preferences between these two sustainable innovations when firms are influenced by the 
external environmental regulations and internal green dynamic capability, and moreover, whether their choices will contribute to shareholders' profits or not.

\subsection{The Effect of Environmental Regulation on Sustainable Innovation}

The main goal of government environmental regulation is to achieve harmonious development of environment and industry. Thus, the government needs to formulate relevant environmental policies according to the development situation, organizational structure, and existing resources. Based on Porter Hypothesis, appropriate environmental regulation can promote firms' innovation.

Considering the link of environmental regulation and innovation performance, the results are categorized into two aspects. Firstly, from the perspective of Cost Compensation Theory, a group of scholars explain that the implementation of environmental regulation increases the management cost of firms, thereby reducing the investment in innovation activities, thus inhibiting the innovative production of firms [52]. Secondly, in the view of innovation compensation, scholars argued that in order to gain competitive edges, these firms will be autonomous in their innovation activities to achieve efficient production, while the government and society will also take measures to stimulate and induce firms to carry out green innovation [53]. Furthermore, governments' environmental standards punish firms that violate the rules, thus encouraging other firms to comply with regulations that help firms to develop innovation activities. The sustainability exploitation innovation requires firms to emphasize the use of existing innovation resources and innovation practices [47]. Thus, sustainability exploration innovation and sustainability exploitation innovation can achieve the balance between economic development and environmental protection via enhancing sustainable innovation [54].

In view of innovation, exploration, and exploitation, innovations portray two different methods to attain innovative results for business organizations. Thus, environmental regulation promotes technology innovation. For instance, improving the efficiency of sustainability exploitation innovation tools and methods. From cost compensation perspective, environmental regulation force firms to implement innovative practices, thus, organizations may orchestrate their production resources and improve technology to meet the governments' needs. This helps develop following hypotheses:

Hypothesis 1a. Environmental regulation positively affects sustainability exploitation innovation.

Hypothesis 1b. Environmental regulation positively affects sustainability exploration innovation.

\subsection{The Effect on Environmental Regulation on Green Dynamaic Capability}

Environmental regulation requires firms to implement environmental management, and increase investment in innovation related to environmental protection and pollution reduction [25]. Environmental regulation requires firms, which aim to avoid green risks, to adjust green producing strategy in a certain period [35]. Furthermore, environmental regulation highlights the importance of reconfiguring internal resources, enhancing green produce line, and orchestrating human structure [55]. Environmental regulation has led to environmental changes, enabling firms to face a new market environment, in which they pay more attention to green innovation, environmental protection, pollutant emission reduction, energy, and material consumption [56].

According to the Dynamic Capability Theory, when facing the challenges from the dynamic environment, firms will integrate, establish, and reconfigure competences to gain competitiveness [57,58]. Relative to dynamic capability, green dynamic capability are regarded as the capability of a firm to integrate and reconfigure its existing resources and knowledge to renew and develop its green organizational capability $[40,43]$. Green dynamic capability is critical to firm success, in response to environmental protection, and shortages of resources and energy. To obtain green competitive edge, firms are motivated to take environmentally friendly productions by improving the capability to sense, seize, and orchestrate opportunities in the markets.

Thus, we proposed the following hypothesis: 
Hypothesis 1c. Environmental regulation positively affects green dynamic capability.

\subsection{The Effect of Green Dynamci Capability}

The core point of sustainable development is integrating financial performance, environment, society, and other government control factors appropriately [59]. The improvement of firms' green dynamic capability allows for firms to make efficient adjustment to adapt to the changes of the green environment. On the one hand, it reorganizes the existing resources to achieve the optimal allocation. On the other hand, it also recognizes and seizes the opportunities of environmental chances to create the competitive edge of competitors. The establishment of competitive edges is positively associated with the sustainable production and innovation of products.

Sustainable practices will help firms achieve a high level of financial performance [60]. At the sensing level of dynamic capability, firms will undertake a series of innovation activities to capture customer needs, competitor information, and explore innovation opportunities $[61,62]$ found that the lack of clean production technology and measures to address cleaner production will be the main obstacle to high-quality development for firms. Therefore, the capability to obtain information in the external environment quickly is inaccessible for firms to move to high-quality development. At the seizing level of dynamic capability, organizations will mobilize existing resources to capture opportunities and challenges. Since the high-quality development of the firms is affected by the internal organizational structure and external stakeholders, it is beneficial to the sustainable development activities if they can coordinate internal and external resources and fully mobilize it [63]. By constantly adjusting the organizational resources, the firms can enhance sustainable competitive edges. Further, in order to achieve high financial performance, organizations should learn how to update, use, and allocate resources to a rapidly changing external environment $[44,64]$. This leads us to suggest the following hypothesis:

Hypothesis 2. Green dynamic capability positively affects financial performance.

Green dynamic capability that emphasizes the use of existing green resources and capability, helps firms to meet the changing needs of the external environment by constructing and developing new organizational capability [65]. On the one hand, green dynamic capability helps firms to achieve a timely understanding of environmental protection laws, regulations, and policies, and quickly perceive and capture the subtle dynamic changes in the market by conducting an extensive information search [43]. Firms with strong green dynamic capability are more likely to fully grasp consumers' green demands and the future development trend of the industry. On the other hand, firms with strong green dynamic capability can adjust the production process effectively according to changes in actual demand [66]. Therefore, we believe that green dynamic capability can help firms to promote sustainable innovation, and improve the probability of success of green innovation by overcoming technical research and development difficulties.

Therefore, we propose following hypotheses:

Hypothesis 3a. Green dynamic capability positively affects financial performance via sustainability exploitation innovation.

Hypothesis 3b. Green dynamic capability positively affects financial performance via sustainability exploration innovation.

\subsection{The Effect of Sustainable Innovation on Financial Performance}

The impact of innovation activities on firms' economic output is also considered within two aspects. Some scholars insisted that sustainability exploratory innovation and sustainability exploitation innovation promoted the financial performance of firms to varying degrees [67]. In contrast, other scholars believed that the relationship between the two kinds of sustainable innovation and corporate 
financial performance was not directly related. For instance, [68] concluded that exploratory practice and financial performance in sustainable innovation were inverted due to the intensity of research and development and the influence of the firms' industry. [47] recommended that the main goal of sustainability exploration innovation is to new climate-friendly products and technology by conducting the exploration innovation.

Sustainability exploration innovation covers both sustainable development and exploration innovation, which aims to reduce the environmental impact of the product cycle via conducting exploration innovation [24,69]. New green products, technologies, and knowledge created by sustainability exploration innovation are beneficial to reduce material consumption and increase recycling rates [70]. Therefore, we believe that sustainability exploration innovation is able to explore new markets and differentiate the business from its competitors via providing new green products and green processes [54,71,72]. Additionally, sustainability exploitation innovation aims to continually reduce the use of materials and energy to enhance existing competitive edge eventually through exploitation innovation that pays attention to improving the existing products and designs [49]. It implies that sustainability exploitation innovation ensures the organization's viability against competitors by providing lower prices and higher quality products. Therefore, the sustainability exploitation innovation will improve business performance by developing the nature of innovation. Thus, we proposed following hypotheses:

Hypothesis 4a. Sustainability exploitation innovation positively affects financial performance.

Hypothesis $4 \mathbf{b}$. Sustainability exploratory innovation positively affects financial performance.

\subsection{The Mediating Effect of Sustainable Innovation}

We proposed in Hypotheses H1a and H1b that environmental regulation positively influences two types of sustainable innovation: Sustainability exploitation innovation and sustainability exploration innovation, respectively. After that, we furthermore proposed in Hypotheses H3a and H3b that sustainability exploitation innovation and sustainability exploration innovation can improve the financial performance of manufacturing firms. Therefore, according to Hypotheses H1a and H3a, we argue that environmental regulation forces firms to enhance sustainability exploitation innovation to improve economic development and enhance the environmental protection which can improve their financial performance. Further, following the views proposed in Hypotheses H1b and H3b, we also believe that environmental regulation forces firms to enhance sustainability exploration innovation to achieve the balance between economic development and environmental protection, which can improve their financial performance. Thus, the following hypotheses are proposed:

Hypothesis 5a. The link between environmental regulation and financial performance is mediated by sustainability exploitation innovation.

Hypothesis $\mathbf{5 b}$. The link between environmental regulation and financial performance is mediated by sustainability exploration innovation.

\subsection{The Mediating Effect of Green Dynamic Capability}

Besides exploring the internal mechanism of sustainable innovation, scholars begin to take the influence of the organizational factors of firms into account [16]. According to the Porter Hypothesis, environmental regulation promotes innovation activities, and how to implement and identify innovation activities depends on the dynamic control of internal organizational environment.

Firms tend to enhance the capability to identify innovation opportunities, control risks, and integrate resources when considering the high-level cost caused by a series of factors, e.g., resource shortage of human capital and technology backwardness. At the same time, taking the pressure of 
stakeholders into account, environmental regulation is likely to affect internal organization factors, e.g., leaders' judgment, skills, processes, production techniques, which are key elements of green dynamic capability. Thus, the improvement of dynamic capability depends on flexible and suitable regulations [8], which contributes to the higher economic output.

Meanwhile, considering the influence of environmental regulation, firms improve the effectiveness of innovation activities by changing the uncertain external factors, and reconfigure the factors of organizational rules within the organization. Thus, the effective use of organizational resources and the improvement of organizational structure flexibility are likely to affect the sustainable application of dynamic capability. By then, it makes firms quickly respond to the green markets' changes. Thus, we propose the following hypothesis:

Hypothesis 6. The effect of environmental regulation on financial performance is mediated by green dynamic capability.

\subsection{The Multiple Mediating Role of Green Dynamic Capability and Sustainable Innovation}

Green dynamic capability presents the capability of firms to adapt to external changes by using internal and external green resources, and firms with higher class of green dynamic capability can obtain great merits in realizing green innovation and development. According to Hypotheses $\mathrm{H} 1 \mathrm{c}, \mathrm{H3a}$, and H4a, firms need to enhance their green dynamic capability to cope with changes caused by environmental regulation, and the strengthening of green dynamic capability may promote the implement of sustainability exploitation innovation, which is critical driver to improve firms' financial performance.

As proposed in hypothesis H1c, environmental regulation is positively associated with green dynamic capability. According to $\mathrm{H} 3 \mathrm{~b}$ and $\mathrm{H} 4 \mathrm{~b}$, green dynamic capability have a positive impact on sustainability exploration innovation via improving reconfiguration and opportunity recognition capability of a firm, and sustainability exploration innovation can improve firms' financial performance. Therefore, based on the $\mathrm{H} 1 \mathrm{c}, \mathrm{H} 3 \mathrm{~b}$, and $\mathrm{H} 4 \mathrm{~b}$, this study believes that environmental regulation can enhance firms' financial performance via green dynamic capability and sustainability exploration innovation.

Based on the above discussion, we therefore hypothesize:

Hypothesis 7a. The influence of environmental regulation on financial performance is subsequently mediated by green dynamic capability and sustainability exploitation innovation.

Hypothesis $\mathbf{1 b}$. The influence of environmental regulation on financial performance is subsequently mediated by green dynamic capability and sustainability exploration innovation.

According to hypotheses above, the conceptual framework proposed in this study is shown in Figure 1.

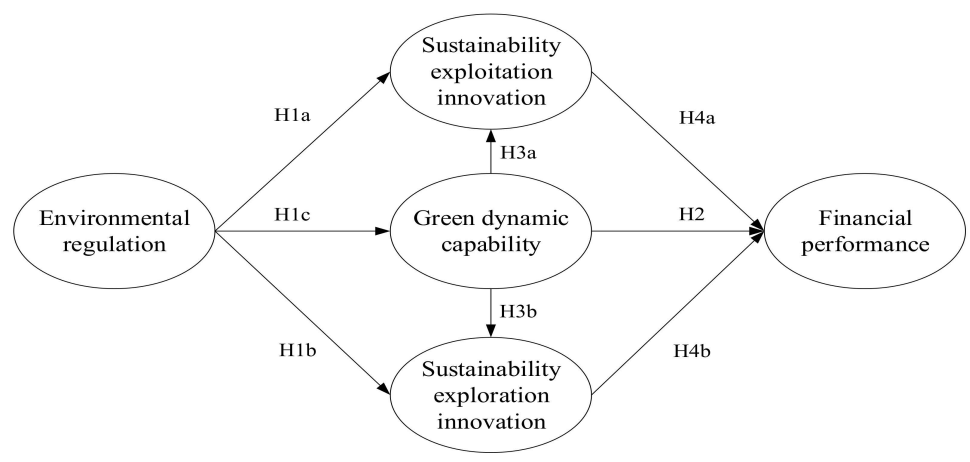

Figure 1. The conceptual framework 


\section{Research Methodology}

Following previous studies [24,41,73], the research methodology is conducted in the following three stages. First, these survey questionnaires were firstly designed based on previous studies and confirmed by three professors and senior managers. Second, the questionnaires were randomly sent to a sample of senior managers in manufacturing firms. Third, the validity and reliability of the measurement in this study were assessed to ensure their adequacy for PLS-SEM analysis.

\subsection{Data Collection}

Our research subjects are manufacturing firms in China, and the questionnaires are filled in anonymously by the senior executives of the firm under investigation. The survey, which lasted from March to May in 2018, included the eastern, central, western, and north-eastern regions of China. The questionnaire in this study consists of two parts. The first part includes basic information of firms, and the second part mainly investigates the financial status of firms, the state of sustainable innovation of firms, and the firms' green dynamic capability. To ensure the validity of the questionnaire, three experts from universities and five top managers from manufacturing firms in Wuxi were invited to conduct a preliminary survey, and according to the professional and business executive feedback, the questionnaire was revised and improved.

This study issues 877 questionnaires in the study, e-mail, and online forms, a total of 585 questionnaires were recovered, the recovery rate of $66.70 \%$. Among all received questionnaires, 230 invalid questionnaires that have obvious problems, e.g., incomplete filling, selecting one result for all questions, and obvious regularity were eliminated. Finally, 355 valid questionnaires were obtained, with an efficiency of $60.68 \%$.

According to the preliminary analysis, firm scales cover micro-firms (less than 20 employees; 2.82\%), small firms (from 20 to 299 employees; 36.06\%), medium-sized firms (from 300 to 999 employees; $27.89 \%$ ), and large firms (more than 1000 employees; 33.24\%). In terms of the establishment of firms, the establishment of 1 to 5 years of the firm accounted for $7.04 \%$, the establishment of 6 to 10 years of firms accounted for $22.25 \%$, the establishment of 11 years to 15 years of firm exhibition $14.93 \%$, the establishment of 16 years to 20 years of firms accounted for $22.25 \%$, the establishment of more than 20 years of firms accounted for $33.52 \%$.

In order to reduce the influence of common method variance (CMV), this study distributes the composition measurements of the questionnaire among different subject modules by reference to the method proposed by [74]. In order to verify whether there is a common method deviation, this study uses Harman single factor test to carry out exploratory factor analysis, extracting factors with characteristic values greater than 1 without rotation. The results present that the first factor extracted can only explain the variation of $31.41 \%(<40 \%)$, which indicates that there is no homologous deviation in the obtained data.

\subsection{Variables}

\subsubsection{Dependent Variables}

Financial Performance. Financial performance is defined as the indicator staking the business situation of a firm, which can directly reflect the profitability and business risk. Referring to the prior study [75], this study tested financial performance with 3 items (sales growth, profitability, and market share in the main product market) in which, managers were asked to rate financial performance relative to that of their major competitors. Respondents self-reported all the items through 7-point Likert scales ranging from 1 (strongly disagreement) to 7 (strongly agreement).

\subsubsection{Independent Variables}

Environmental Regulation. Environmental regulation represents a series of policies for governments to achieve environmental innovation in order to achieve environmental protection and economic 
development [76]. Reference to multi-item construct used by prior studies [77], this study measured environmental regulation through four items through a 7-point Likert scale ranging from 1 (strongly disagreement) to 7 (strongly agreement). Managers were asked to explain the extent to which environmental regulations affected his or her firms, including (1) strict criteria, (2) suitability for China's situation, (3) being aware of their impact, and (4) whether environmental issues can be effectively addressed.

\subsubsection{Mediating Variables}

Green Dynamic Capability. This capability refers to the capability to integrate and reconfigure internal and external competences to meet the requirements of changing environments and green product design [40,43]. Following a 7-item construct proposed by [43], we used measured green dynamic capability using the following five items: (1) The firm's capability to quickly monitor the environment, (2) the capability to learn and create, (3) the capability to integrate resources and expertise, (4) the capability to coordinate employees' capability to develop green technologies, and (5) successfully allocate resources to develop the capability to innovate in green.

Sustainability Exploitation Innovation and Sustainability Exploration Innovation. Sustainable innovation is a series of innovative activities to achieve sustainable development, in which sustainability exploitation innovation emphasizes the capability of a firm to participate in and improve the production process [71]. Sustainability exploration innovation refers to the process by which firms establish divergent and innovative adaptive mechanisms through their own practices [47]. Based on prior studies [49], sustainability exploitation innovation was measured using the following six items: (1) Our firm promptly responds to issues proposed by existing stakeholders; (2) our firm often focuses on evaluating external factors related to the interests of key stakeholders; (3) our firm conducts the proactive and flexible business procedures, giving support to meet the various demands of key stakeholders; (4) our firm's product/service design and development often reflect the requirement of key customers and suppliers; (5) our firm often takes advantage of various management measures to avoid risks of variability in key processes; (6) our firm often encourages members to meet sustainability standards via setting a series of key performance indicators. Each of these items was measured using a 7-point Likert scale ranging from 1 (totally disagree) to 7 (totally agree).

According to prior studies [24,51], sustainable product and process development (SER-SPPD) and sustainable-oriented learning (SER-SOL) constitute sustainability exploration innovation. SER-SPPD usually refers to green process engineering and product innovation. SOL usually refers to the capability to develop sustainability- related innovations. Reference to prior studies [24,71], SER-SPPD was measured using the following four items: (1) Our firm is likely to develop products or services in a radical way to face environmental changes; (2) our firm strives to reduce the negativity of external environment via the improvement of the products or services; (3) our firm reconfigures the business procedures periodically to meet green needs; (4) our firm often obtains environmentally friendly innovation to build green environment. SER-SOL was measured using the following four items: (1) Our firm often attaches great importance to train the knowledge and skills of workers to make sustainability practices more effectively; (2) our firm strives to form a sustainable organizational culture by enhancing innovative learning; (3) our firm is good at giving sustainable examples to enhance the capability of workers involving knowledge and practical skills; (4) our firm identifies external opportunities from partners to obtain ideas toward sustainability. Each of these items was measured using a 7-point Likert scale ranging from 1 (strongly disagreement) to 7 (strongly agreement).

\subsubsection{Control Variables}

Prior literature indicated that same unobservable determinants may jointly influence financial performance $[78,79]$. Following them, we control observable variables to mitigate bias caused by unobservable determinants. The existing literature presents that the basic features of firm, e.g., firm size and age, can influence the green innovation behavior of firm, and this study designs firm size and firm 
age as control variables [80]. Referring to [54,81], we use the natural arithmetic of business years to portray firm age, and use the natural arithmetic of the average number of staff in the past three years to portray firm size.

\subsection{Reliability Test}

To calculate the validity and reliability of the measurement, PLS-SEM model and SmartPLS 3.0 software were employed in this study. Following to prior studies [82,83], we measure the convergent validity of the scales following three principles ( all indicator loadings $>0.70$; Composite Reliabilities $>$ 0.60 ; the average variance extracted $>0.50$ ). All outer factor loadings for constructed items range from 0.742 to $0.861(>0.70)$ as shown in Table 1, the Composite Reliabilities values range from 0.879 to 0.913 $(>0.60)$, and the average variance extracted ranges from 0.603 to $0.708(>0.50)$. All three conditions for convergent validity thus hold. Additionally, Table 1 presents that Cronbach's $\alpha$ values range from 0.794 to 0.880 , which exceeded the suggested threshold value of 0.70 . The results of the reliability test show that a set of indicators in this study can explain a single latent construct [84].

Table 1. Reliability and convergent validity $(\mathrm{N}=355)$.

\begin{tabular}{|c|c|c|c|c|c|}
\hline Variable & $\begin{array}{l}\text { Measurement } \\
\text { Items }\end{array}$ & $\begin{array}{l}\text { Factor } \\
\text { Loadings }\end{array}$ & Cronbach's $\alpha$ & CR & AVE \\
\hline \multirow{5}{*}{$\begin{array}{l}\text { Environmental } \\
\text { regulation } \\
\text { (ER) }\end{array}$} & ER1 & 0.825 & \multirow{5}{*}{0.847} & \multirow{4}{*}{0.897} & \multirow{4}{*}{0.685} \\
\hline & ER2 & 0.839 & & & \\
\hline & ER3 & 0.804 & & & \\
\hline & ER4 & 0.842 & & & \\
\hline & SEI1 & 0.782 & & \multirow{6}{*}{0.901} & \multirow{6}{*}{0.603} \\
\hline \multirow{5}{*}{$\begin{array}{c}\text { Sustainability } \\
\text { exploitation innovation } \\
\text { (SEI) }\end{array}$} & SEI2 & 0.781 & \multirow{5}{*}{0.868} & & \\
\hline & SEI3 & 0.771 & & & \\
\hline & SEI4 & 0.781 & & & \\
\hline & SEI5 & 0.801 & & & \\
\hline & SEI6 & 0.742 & & & \\
\hline \multirow{4}{*}{$\begin{array}{c}\text { Sustainability-oriented } \\
\text { learning } \\
\text { (SER-SOL) }\end{array}$} & SER-SOL1 & 0.831 & \multirow{4}{*}{0.838} & \multirow{4}{*}{0.892} & \multirow{4}{*}{0.673} \\
\hline & SER-SOL2 & 0.833 & & & \\
\hline & SER-SOL3 & 0.798 & & & \\
\hline & SER-SOL4 & 0.821 & & & \\
\hline \multirow{5}{*}{$\begin{array}{l}\text { Sustainable product and } \\
\text { process development } \\
\text { (SER-SPPD) }\end{array}$} & SER-SPPD1 & 0.857 & \multirow{5}{*}{0.857} & \multirow{5}{*}{0.903} & \multirow{4}{*}{0.701} \\
\hline & SER-SPPD2 & 0.833 & & & \\
\hline & SER-SPPD3 & 0.824 & & & \\
\hline & SER-SPPD4 & 0.834 & & & \\
\hline & GDC1 & 0.859 & & & \\
\hline \multirow{4}{*}{$\begin{array}{l}\text { Green dynamic } \\
\text { capability } \\
\text { (GDC) }\end{array}$} & GDC2 & 0.800 & \multirow{4}{*}{0.880} & \multirow{4}{*}{0.913} & \multirow{4}{*}{0.677} \\
\hline & GDC3 & 0.846 & & & \\
\hline & GDC4 & 0.794 & & & \\
\hline & GDC5 & 0.811 & & & \\
\hline \multirow{3}{*}{$\begin{array}{l}\text { Financial performance } \\
\text { (FP) }\end{array}$} & FP1 & 0.831 & \multirow{3}{*}{0.794} & \multirow{3}{*}{0.879} & \multirow{3}{*}{0.708} \\
\hline & FP2 & 0.861 & & & \\
\hline & FP3 & 0.833 & & & \\
\hline
\end{tabular}

Note: AVE: average variance extracted; CR: composite reliability.

\subsection{Descriptive Statistics and Correlation Analysis}

To examine the discriminant validity, we compare the square root of the AVE with the coefficients of correlation between the variable and other variables. The results of correlation statistics and discriminant validity are presented in Table 2 that presents the mean, standard deviation, the square root of AVE, and the correlation between variables. The square root of AVE for each variable is higher than the correlation coefficient between the variable and the other potential variables, which indicate that the discriminant validity of all variables is acceptable. 
Table 2. Descriptive statistics and discriminant validity.

\begin{tabular}{lccccccccc}
\hline Variable & Mean & $\begin{array}{c}\text { Standard } \\
\text { Deviation }\end{array}$ & $\mathbf{1}$ & $\mathbf{2}$ & $\mathbf{3}$ & $\mathbf{4}$ & $\mathbf{5}$ & $\mathbf{6}$ \\
\hline 1. ER & 5.612 & 0.912 & $\underline{\mathbf{0 . 8 2 8}}$ & & & & & \\
2. SEI & 5.325 & 0.851 & $0.428^{* *}$ & $\underline{\mathbf{0 . 7 7 7}}^{* *}$ & & & & \\
3. SER-SOL & 5.492 & 0.884 & $0.330^{* *}$ & $0.622^{* *}$ & $\underline{\mathbf{0 . 8 2 0}}^{* *}$ & & & \\
4. SER-SPPD & 5.364 & 1.021 & $0.347^{* *}$ & $0.558^{* *}$ & 0.437 & & \\
5. GDC & 5.086 & 1.134 & $0.537^{* *}$ & $0.572^{* *}$ & $0.472^{* *}$ & $\underline{0.484}^{* *}$ & $\underline{\mathbf{0 . 8 2 3}}^{* *}$ & \\
6. FP & 5.438 & 1.026 & $0.332^{* *}$ & $0.571^{* *}$ & $0.557^{* *}$ & $0.464^{* *}$ & 0.601 & $\underline{\mathbf{0 . 8 4 1}}$ \\
\hline
\end{tabular}

Note: ${ }^{*} p<0.05 ; * * p<0.01$. The square roots of AVE are shown in diagonal line. ER: Environmental regulation; SEI: Sustainability exploitation innovation; SER-SOL: Sustainability-oriented learning; SER-SPPD: Sustainable product and process development; GDC: Green dynamic capability; FP: Financial performance.

\section{Results}

To examine the research hypotheses, the partial least squares approach to structural equation modeling (PLS-SEM) was applied. Following the PLS specific evaluation process [41], we evaluate the PLS-SEM model by using the SmartPLS 3.0 software, and then interpreted the path coefficients and evaluated the significances by bootstrapping (1000 subsamples and individual-level changes reprocessing).

\subsection{Direct Effects}

To examine H1a and H1b, the results in Table 3 and Figure 2 indicate that the direct effects of environmental regulation on sustainability exploitation innovation and sustainability exploration innovation are different. Environmental regulation has a positive effect on sustainability exploitation innovation $(\beta=0.053, p<0.001)$. However, the effect of environmental regulation on SER-SOL $(\beta=0.115, p>0.100)$ and SER-SPPD $(\beta=0.136, p>0.050)$ are not significant. Therefore, H1a is supported, but $\mathrm{H} 1 \mathrm{~b}$ is not supported. What's more, our results present that the effect of environmental regulation on green dynamic capability is significant $(\beta=0.538, \mathrm{p}<0.100)$, and the $95 \%$ bias-corrected confidence interval ranges from 0.446 to 0.612 , which does include 0 . Therefore, H1c is supported.

Table 3. Results for the direct effects $(\mathrm{N}=355)$.

\begin{tabular}{|c|c|c|c|c|c|}
\hline \multirow{2}{*}{$\begin{array}{l}\text { Corresponding } \\
\text { Hypothesis }\end{array}$} & \multirow{2}{*}{ Direct Effect } & \multirow{2}{*}{ Boot Effect } & \multicolumn{2}{|c|}{ Bootstrapping Percentile 95\% CI } & \multirow{2}{*}{ Result } \\
\hline & & & LLCI & ULCI & \\
\hline H1a & $\begin{array}{l}\text { SEI } \\
\text { ER }\end{array}$ & $0.174^{* *}$ & 0.055 & 0.300 & Supported \\
\hline \multirow[t]{2}{*}{$\mathrm{H} 1 \mathrm{~b}$} & $\begin{array}{l}\text { SER-SOL } \\
\text { ER }\end{array}$ & 0.115 & -0.029 & 0.246 & Not supported \\
\hline & $\begin{array}{c}\text { SER-SPPD } \\
\text { ER }\end{array}$ & 0.136 & -0.017 & 0.256 & Not supported \\
\hline $\mathrm{H} 1 \mathrm{c}$ & $\begin{array}{c}\text { GDC } \\
\text { ER }\end{array}$ & $0.538^{* *}$ & 0.446 & 0.612 & Supported \\
\hline $\mathrm{H} 2$ & $\begin{array}{l}\text { FP } \\
\text { GDC }\end{array}$ & $0.366^{* *}$ & 0.245 & 0.481 & Supported \\
\hline H3a & $\begin{array}{c}\text { SEI } \\
\text { GDC }\end{array}$ & $0.481 * *$ & 0.376 & 0.583 & Supported \\
\hline \multirow[t]{2}{*}{$\mathrm{H} 3 \mathrm{~b}$} & $\begin{array}{l}\text { SER-SPPD } \\
\text { GDC }\end{array}$ & $0.409 * *$ & 0.293 & 0.510 & Supported \\
\hline & $\begin{array}{l}\text { SER-SOL } \\
\text { GDC }\end{array}$ & $0.408^{* *}$ & 0.288 & 0.519 & Supported \\
\hline $\mathrm{H} 4 \mathrm{a}$ & $\begin{array}{l}\text { FP } \\
\text { SEI }\end{array}$ & $0.181 * *$ & 0.047 & 0.320 & Supported \\
\hline \multirow[t]{2}{*}{$\mathrm{H} 4 \mathrm{~b}$} & $\begin{array}{c}\text { FP } \\
\text { SER-SOL }\end{array}$ & $0.250 * *$ & 0.124 & 0.387 & Supported \\
\hline & $\begin{array}{c}\text { FP } \\
\text { SER-SPPD }\end{array}$ & 0.103 & -0.003 & 0.199 & Not supported \\
\hline
\end{tabular}

Note: ${ }^{*} p<0.05 ; * * p<0.01$. ER: Environmental regulation; SEI: Sustainability exploitation innovation; SER-SOL: Sustainability-oriented learning; SER-SPPD: Sustainable product and process development; GDC: Green dynamic capability; FP: Financial performance. 


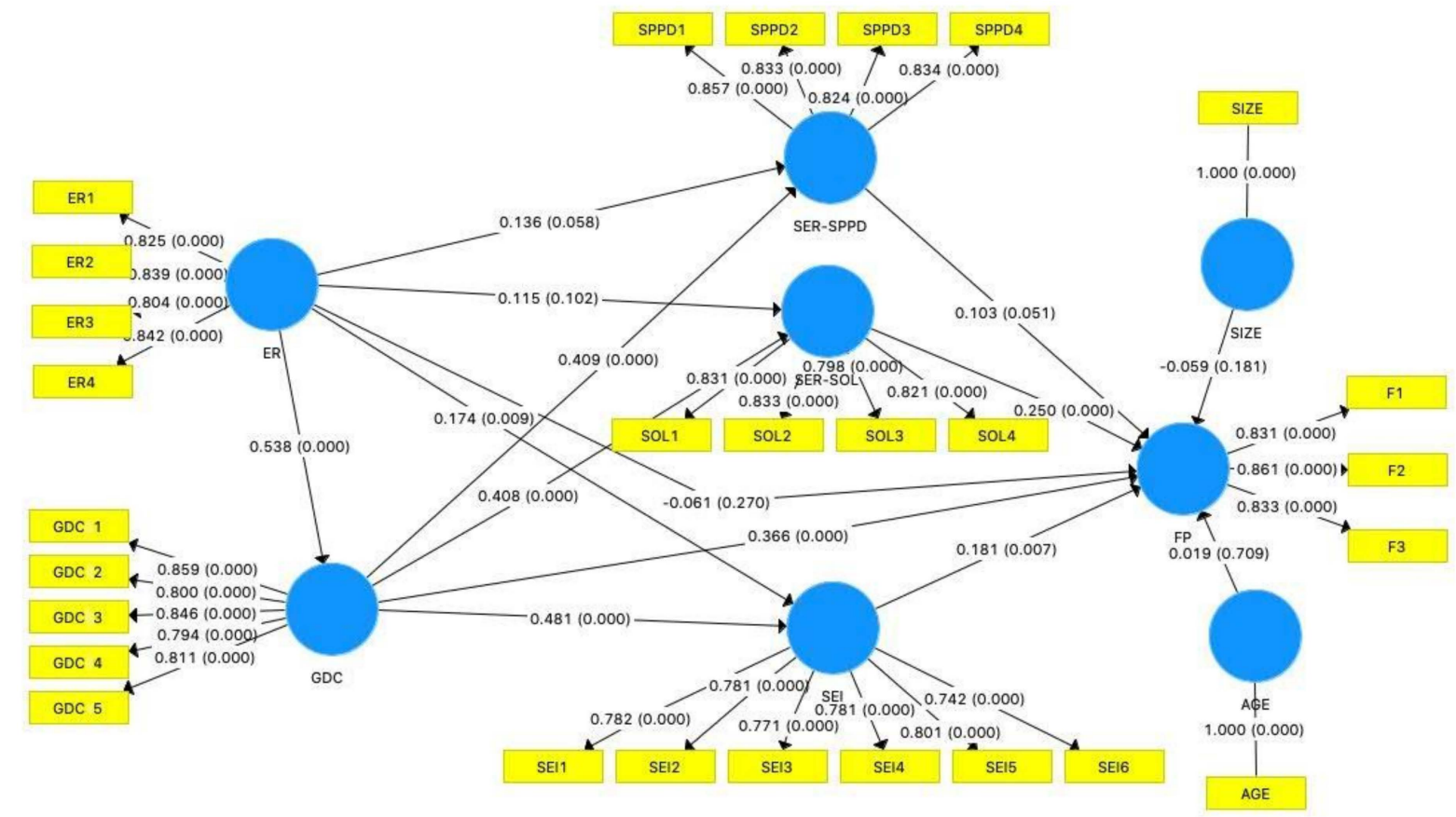

Figure 2. Results of multiple mediation model. Note: ER: Environmental regulation; SEI: Sustainability exploitation innovation; SER-SOL: Sustainability-oriented learning; SER-SPPD: Sustainable product and process development; GDC: Green dynamic capability; FP: Financial performance.

Accordingly, it is found that green dynamic capability positively affects the financial performance ( $\beta=0.366, \mathrm{p}<0.001$ ), the $95 \%$ bias-corrected confidence interval does not include 0 (LLCI $=0.245$, $\mathrm{ULCI}=0.481$ ), thus $\mathrm{H} 2$ is empirically supported. To assess the effect of green dynamic capability on two kinds of sustainable innovation, the results present that there is a significant relationship between green dynamic capability and sustainability exploitation innovation $(\beta=0.481, \mathrm{p}<0.001)$. Additionally, the results also indicate that green dynamic capability can significantly affect sustainability exploration innovation from two dimensions: SER-SOL $(\beta=0.408, \mathrm{p}<0.001)$ and SER-SSPD $(\beta=0.409, \mathrm{p}<0.001)$. Therefore, H3a and H3b are supported.

Since the effects of sustainability exploitation innovation $(\beta=0.181, p<0.001)$ and SER-SOL $(\beta=0.250, p<0.001)$ on financial performance are significant, the effect of SER-SPPD $(\beta=0.103$, $\mathrm{p}>0.005)$ presents an opposite result, and the $95 \%$ bias-corrected confidence interval includes $0 \quad(\mathrm{LLCI}=-0.003$, ULCI $=0.199)$. Therefore, H4a is empirically supported, while H4b is partially supported.

\subsection{Indirect Effects}

To test the mediating effects of sustainability exploitation/exploration innovation and green dynamic capability in line with $\mathrm{H} 5$ and H7, we use the bootstrapping method in SmartPLS 3.0. It is clear from Table 4 that sustainability exploitation innovation plays a meditate effect between environmental regulation and financial performance $(\beta=0.032, \mathrm{p}<0.010)$, the effect is significant with the $95 \%$ bias-corrected confidence interval is between 0.007 and 0.075 . Thus, H5a can be proved. However, the meditating effects of SOL $(\beta=0.029, p>0.100)$ and SPPD $(\beta=0.014, p>0.100)$ on the relationship between environmental regulation and financial are insignificant, which means the mediating role of sustainability exploration innovation in the link of environmental regulation and financial performance is not significant. Thus, the results do not support H5b. 
Table 4. Results for the indirect effects $(\mathrm{N}=355)$.

\begin{tabular}{|c|c|c|c|c|c|}
\hline \multirow{2}{*}{$\begin{array}{l}\text { Corresponding } \\
\text { Hypothesis }\end{array}$} & \multirow{2}{*}{ Indirect Effect } & \multirow{2}{*}{ Boot Effect } & \multicolumn{2}{|c|}{ Bootstrapping Percentile 95\% CI } & \multirow{2}{*}{ Result } \\
\hline & & & LLCI & ULCI & \\
\hline \multirow{4}{*}{ H5a } & FP & & & & \\
\hline & SEI & $0.032 *$ & 0.007 & 0.075 & Supported \\
\hline & ER & & & & \\
\hline & FP & & & & \\
\hline \multirow[t]{4}{*}{$\mathrm{H} 5 \mathrm{~b}$} & $\begin{array}{c}\text { SER-SOL } \\
\text { ER }\end{array}$ & 0.029 & -0.002 & 0.073 & Not supported \\
\hline & FP & & & & \\
\hline & $\begin{array}{c}\text { SER-SPPD } \\
\text { ER }\end{array}$ & 0.014 & -0.001 & 0.042 & Not supported \\
\hline & FP & & & & \\
\hline H6 & GDC & $0.197^{* *}$ & 0.129 & 0.271 & Supported \\
\hline & ER & & & & \\
\hline & FP & & & & \\
\hline \multirow[t]{3}{*}{ H7a } & $\begin{array}{c}\text { SEI } \\
\text { GDC }\end{array}$ & $0.047 *$ & 0.011 & 0.088 & Supported \\
\hline & $\begin{array}{c}\text { GDC } \\
\text { ER }\end{array}$ & & & & \\
\hline & FP & & & & \\
\hline \multirow{5}{*}{$\mathrm{H} 7 \mathrm{~b}$} & SER-SOL & $0.055 *$ & 0.023 & 0.097 & Supported \\
\hline & $\begin{array}{c}\text { GDC } \\
\text { ER }\end{array}$ & 0.000 & & & \\
\hline & FP & & & & \\
\hline & $\begin{array}{l}\text { SER-SPPD } \\
\text { GDC }\end{array}$ & 0.023 & 0.000 & 0.049 & Not supported \\
\hline & ER & & & & \\
\hline
\end{tabular}

Note: ${ }^{*} p<0.05 ; * * p<0.01$. ER: Environmental regulation; SEI: Sustainability exploitation innovation; SER-SOL: Sustainability-oriented learning; SER-SPPD: Sustainable product and process development; GDC: Green dynamic capability; FP: Financial performance.

Regarding H6, the result presents that green dynamic capability positively mediates the relationship between environmental regulation and financial performance, which has a significant value of 0.197 and the $95 \%$ bias-corrected confidence interval is between 0.129 and 0.271 , which does not include 0 . Thus, we conclude that environmental regulation can promote the improvement of firms' green dynamic capability, and thus improve the financial performance.

As can be seen in Table 4, different types of innovation have different influence on the relationship between environmental regulation and financial performance via green dynamic capability. According to H7a, sustainability exploitation innovation plays a significant multi-mediation role in the path of environmental regulation to financial performance $(\beta=0.047, p<0.050)$. The results show that the value is proven to be significant with the $95 \%$ bias-corrected confidence interval between 0.011 and 0.088 , which does not include 0 . Thus, H7a is supported. At the same time, the $95 \%$ bias-corrected confidence interval of the multi-mediation effect composed of green dynamic capability and SER-SOL does not include $0($ LLCI $=0.023$, ULCI $=0.097)$, which indicates that the coefficient of mediating effect is significant $(\beta=0.055, \mathrm{p}<0.050)$. By contrast, green dynamic capability and SER-SPPD cannot mediate the link between environmental regulation and financial performance $(\beta=0.023, p>0.005)$. Therefore, $\mathrm{H7b}$ is partially supported.

\section{Discussions}

Prior studies that noted the importance of environmental regulation in promoting sustainable development have focused on the link between environmental regulation, technology innovation, and firm performance based on the research framework of Porter Hypothesis [2,85]. However, the effect of environmental regulation on innovation and firm performance remains still inconclusive [86]. Suggested by $[20,24,33]$, some key factors within business organizations, e.g., internal capability, organizational slack, and stakeholder pressures etc., be addressed into framework of Porter Hypothesis 
to promote firms to integrate economic development and environmental protection. Few studies has addressed the green dynamic capability into the original Porter Hypothesis and provided empirical evidence that environmental regulation can affect financial performance via green dynamic capability and sustainable innovation. To extend previous studies on Porter Hypothesis, and provide new insights into the framework of Porter Hypothesis consisting of factors within the organization, the existing research was designed to determine the mediating role of green dynamic capability and sustainable innovation in the link between environmental regulation and financial performance.

(1) The meditating role of sustainability exploration/exploitation innovation in the link between environmental regulation and financial performance. Different from the existing literature [87], the most interesting result is that sustainability exploitation plays a mediating role in the relationship between environmental regulation and financial performance, while sustainability exploration innovation does not. These results are in accord with recent studies indicating that environmental regulation affects financial performance via sustainable innovation [88]. Our findings further supported prior research, which perceived that the effect of environmental regulation on financial performance not only depends on different kinds of environment regulations, but also depends on different types of innovation [24,85].

(2) The meditating role of green dynamic capability in the relationship between environmental regulation and financial performance. Our empirical results indicate that green dynamic capability significantly mediates the link between environmental regulation and financial performance. As for the mediating effect of green dynamic capability in the link between environmental regulation and financial performance, our key findings confirm that green significantly mediates the relationship between environmental regulation and financial performance. This provides empirical evidence for the conceptual framework proposed by prior studies [33], that the mediating effect of some internal factors should be considered in testing Porter Hypothesis, e.g., capability, slack resource, and environmental strategy. Additionally, this study expands the dynamic capability literature by introducing green dynamic capability into the framework of Porter Hypothesis.

(3) The multiple moderating effects of green dynamic capability and sustainable innovation. The results present that environmental regulation can not only promote financial performance through green dynamic capability and sustainability exploitation innovation, but also through green dynamic capability and sustainability oriented learning. These results can support prior literature concerning the complex interconnections among environmental regulation, technology innovation, and firm performance $[16,20,24]$. Our findings confirm the conceptual framework proposed by $[16,22]$ and provide empirical evidence for strong vision of Porter Hypothesis. Different from the findings of $[53,87]$, that technology innovation induced by environmental regulation can lead to a higher firm performance, our findings extend the Porter Hypothesis literature by revealing two possible paths to achieve the strong Porter Hypothesis. Additionally, this study also extends prior research $[24,55]$ by the mediating effect of green dynamic capability in the relationship among environmental regulation, innovation, and firm performance.

\section{Conclusions}

Drawing on the Dynamic Capability Theory and the Porter Hypothesis framework, this study introduces a model that tends our knowledge regarding the relationship of environmental regulation and financial performance with multiple mediations of green dynamic capability, and sustainable innovation in manufacturing firms. The main results are as following:

(1) The indirect effect of environmental regulation on financial performance. The result of the analysis of survey data from 355 respondents demonstrate that there is not a significant link between environmental regulation and financial performance, but environmental regulation indirectly affect financial performance via green dynamic capability and sustainability exploitation innovation, respectively.

(2) The multiple mediating effect of green dynamic capability and sustainability exploitation innovating. Our findings indicate that green dynamic capability and sustainability 
exploitation innovation subsequently mediated the link between environmental regulation and financial performance.

(3) The multiple mediating effect of green dynamic capability and sustainability exploration innovating. Environmental regulation also significantly affects financial performance partly through green capability and sustainability exploration innovation. Our findings provide some intriguing insights, especially when compared to the results of the existing literature.

\subsection{Theoretical Implications}

Our study makes contributions to the Porter Hypothesis literature in three ways. First, we established a multiple mediating model involving environmental regulation, green dynamic capability sustainability exploitation/exploration innovation, and financial performance together. We provide a holistic view in the multiple indirect effects of environmental regulation on financial performance through two types of sustainable innovation. Our findings indicated that strong Porter Hypothesis not only depends different types of environmental regulations and industry heterogeneity [89], but also depends on different types of sustainable innovation. These findings provide an insight into the role of sustainability exploitation innovating in the implement of strong Porter Hypothesis.

Second, our findings suggest that the strong vision of Porter Hypothesis not only depends on different kind of environmental regulations and technology innovation, but is also related to internal organization factors. The results of this study further enrich the research on green dynamic capability by uncovering the mediating effect of green dynamic capability in the link between environmental regulation and financial performance.

Third, prior studies related to the Porter Hypothesis have focused on the link between environmental regulation and technology innovation, and neglected the effect of factors internal to firms. This study enriches the literature by arguing the multiple mediating effects of green dynamic capability and sustainability exploration/exploitation innovations on the link between environmental regulation and financial performance. Our findings indicate that green dynamic capability respond the internal and external model when organizations complying with the environmental regulations.

\subsection{Practical Implications}

The empirical evidences offer following implications for practitioners. We find the optimize way innovation for firms to gain economic output. Environmental regulation will bring firms the actual development risks, and at the same time, low dynamic capability is likely to result in lack of competitive edge for firms [90]. With the rapid development of China's economy, environmental regulation not only directly affects sustainable innovation, but also sets up an invisible "access standards" for firms' green dynamic capability. It can be seen that the green dynamic capability play an important effect in the mechanism of environmental regulation. As small and medium-sized firms, organizing sustainability exploitation innovation activities may lead to more efficient innovation benefits, e.g., leasing innovative equipment and outsourcing innovative production. By contrast, for innovative firms, it is clear that perfecting their organizational structure will gain first priority. They can implement exploration innovation practices on the basis of maintaining a certain level of sustainability exploitation innovation, e.g., the production innovation, human resource cultivation, and management model innovation.

When it comes to government measures, we provide theoretical suggestions to high-quality development in line with Chinese manufacturing firms. Properly transmitting information to firms benefit firms to identify opportunities, control risks, and orchestrate relevant resources. At the same time, governments need to coordinate regulatory systems and enhance sustainability exploitation innovation models, including leasing systems and outsourcing systems. In that case, it will be easier to maintain the fairness and competitiveness of activities related to sustainability exploitation innovation. Most importantly, the government had better encourage firms towards sustainability exploration innovation appropriately, since it may be helpful to organizations' long-term goals [51]. 
As an inevitable element when analyzing the internal influence mechanism of environmental regulation, green dynamic capability portray firms' original capability react to the environmental policies. The results of this study point out green dynamic capability take an important part in the relationship between environmental regulation and firm performance. First, the high level of green dynamic capability of firms directly facilitates the financial performance, for the reason that firms are able to rapidly make risk identification, capital control, and market monitoring. Second, environmental regulation improves the efficiency of the organization's management pattern by changing the internal structure of the organization. Finally, the environmental regulation affects the internal organizational structure through changes in external market environments and innovative activities in the internal organizations, which contributes to efficient production lines and new products. The process enhances the reputation of firms to a certain extent, and contributes to high financial performance of firms [91,92].

With respect to sustainable innovation, it is found that sustainability exploitation innovation is more in line with the current trend of Chinese manufacturing firms than sustainability exploration innovation. It means that firms prefer to improve their performance by purchasing patents, and outsourcing production. This is because that the success rate of exploratory product innovation is relatively low along with high financial risks, so most firms that have difficulty transforming exploration innovation avoid radical innovation to reduce potential economic lose. At the same time, sustainability exploitation innovation and green dynamic capability have a multiple mediating effect on the link between environmental regulation and financial performance, since the government's requirements for high-quality development affect the capability of firms to perceive opportunities, control resource structure, and reconfigure resources, thus changing the innovation model. In terms of sustainability exploration innovation, sustainability-oriented learning plays a more obvious effect than sustainable product and process development. We also find the intermediary effect of sustainable product and process innovation is insignificant, thus, firms prefer to adopt sustainability exploitation innovation and sustainable orientation innovation to create innovative value. Accordingly, firms need to carry out more sustainable learning activities when resources are limited.

\subsection{Limitation and Future Research}

There are some limitations in this study which need to be further explored. First, this study only gives insight into the performance of firms at a certain point in time, since it is much more complex to collect long-term and stable firm data. In order to explore the long-term rewards of sustainability exploitation innovation, future research should be analyzed in long-term scenarios. Second, there may be different types of environmental regulation, e.g., mandatory and voluntary regulations, and it is preferable to investigate the different functions of them on green dynamic capability and sustainable innovation activities. Additionally, this study explored the effect of environmental regulation on financial performance via green dynamic capability, and sustainable innovation using the data sets were obtained through questionnaires. This leads to the lack of consideration of objective indicators. Therefore, future studies should be replicated by using the objective measurement methods of financial performance (e.g., ROA, profits, Tobin's Q) and innovation

performance (e.g., patents, $R \& D$ input, and $R \& D$ personnel) to explore the effect different types of environmental regulations on financial performance. Third, this study takes 355 manufacturing firms as a sample and tests the inherent mechanism of environmental regulation, green dynamic capability, sustainability exploration/exploitation innovation, and financial performance. It is worthwhile to identify the universality in other industrials. Finally, the existing literature has confirmed the important role of some internal dynamics (e.g., social responsibility, stakeholder pressure) in promoting the implement of sustainable innovation and improving financial performance. Therefore, future research can properly explore how to introduce these internal dynamics into the framework of Porter Hypothesis to explore potential channels to achieve sustainable development. 
Author Contributions: Conceptualization, J.W.; methodology, X.X. and L.S.; software, X.X.; investigation, X.X. and T.L.; data curation, X.X. and L.S.; writing-original draft preparation, X.X. and T.L.; writing-review and editing, J.W. and T.L.; supervision, J.W. All authors have read and agreed to the published version of the manuscript.

Funding: This study is funded by the National Natural Science Foundation of China (Grant No. 71673115), the Jiangsu Social Science Fund (Grant No. 19GLC004), and the Philosophy and Social Science Research Planning Project of Heilongjiang Province (Grant No. 19JLC117).

Conflicts of Interest: The authors declare no conflict of interest.

\section{References}

1. Wang, X.; Sun, C.; Wang, S.; Zhang, Z.; Zou, W. Going green or going away? A spatial empirical examination of the relationship between environmental regulations, biased technological progress, and green total factor productivity. Int. J. Environ. Res. Public Health 2018, 15, 1917. [CrossRef] [PubMed]

2. Hashmi, R.; Alam, K. Dynamic relationship among environmental regulation, innovation, $\mathrm{CO}_{2}$ emissions, population, and economic growth in OECD countries: A panel investigation. J. Clean. Prod. 2019, 231, 1100-1109. [CrossRef]

3. Searchinger, T.D.; Wirsenius, S.; Beringer, T.; Dumas, P. Assessing the efficiency of changes in land use for mitigating climate change. Nature 2018, 564, 249-253. [CrossRef] [PubMed]

4. Ashford, N.A.; Hall, R.P. Achieving global climate and environmental goals by governmental regulatory targeting. Ecol. Econ. 2018, 152, 246-259. [CrossRef]

5. Costa-Campi, M.T.; García-Quevedo, J.; Martínez-Ros, E. What are the determinants of investment in environmental R\&D? Energ Policy 2017, 104, 455-465.

6. Khan, Z.; Sisi, Z.; Siqun, Y. Environmental regulations an option: Asymmetry effect of environmental regulations on carbon emissions using non-linear ARDL. Energy Sources Part A Recover. Util. Environ. Eff. 2019, 41, 137-155. [CrossRef]

7. Inigo, E.A.; Albareda, L. Sustainability oriented innovation dynamics: Levels of dynamic capabilities and their path-dependent and self-reinforcing logics. Technol. Forecast. Soc. Change 2019, 139, 334-351. [CrossRef]

8. Bitencourt, C.C.; de Oliveira Santini, F.; Ladeira, W.J.; Santos, A.C.; Teixeira, E.K. The extended dynamic capabilities model: A meta-analysis. Eur. Manag. J. 2019. [CrossRef]

9. Cristina De Stefano, M.; Montes-Sancho, M.J.; Busch, T. A natural resource-based view of climate change: Innovation challenges in the automobile industry. J. Clean. Prod. 2016, 139, 1436-1448. [CrossRef]

10. Liu, X.; Wang, E.; Cai, D. Environmental regulation and corporate financing-quasi-natural experiment evidence from China. Sustainability 2018, 10, 4028. [CrossRef]

11. Ford, J.A.; Steen, J.; Verreynne, M.L. How environmental regulations affect innovation in the Australian oil and gas industry: Going beyond the Porter Hypothesis. J. Clean. Prod. 2014, 84, 204-213. [CrossRef]

12. Zhao, X.; Liu, C.; Yang, M. The effects of environmental regulation on China's total factor productivity: An empirical study of carbon-intensive industries. J. Clean. Prod. 2018, 179, 325-334. [CrossRef]

13. Porter, M.E.; Van Der Linde, C. Toward a new conception of the environment-competitiveness relationship. J. Econ. Perspect. 1995, 9, 97-118. [CrossRef]

14. Lanoie, P.; Laurent-Lucchetti, J.; Johnstone, N.; Ambec, S. Environmental policy, innovation and performance: New insights on the porter hypothesis. J. Econ. Manag. Strateg. 2011, 20, 803-842. [CrossRef]

15. Li, M.; Dong, L.; Luan, J.; Wang, P. Do environmental regulations affect investors? Evidence from China's action plan for air pollution prevention. J. Clean. Prod. 2020, 244. [CrossRef]

16. Nor, N.M.; Bahari, N.A.S.; Adnan, N.A.; Kamal, S.M.Q.A.S.; Ali, I.M. The Effects of Environmental Disclosure on Financial Performance in Malaysia. Procedia Econ. Financ. 2016, 35, 117-126. [CrossRef]

17. Dou, J.; Han, X. How does the industry mobility affect pollution industry transfer in China: Empirical test on Pollution Haven Hypothesis and Porter Hypothesis. J. Clean. Prod. 2019, 217, 105-115. [CrossRef]

18. Kalt, J.P. The impact of domestic environmental regulatory policies on US international competitiveness. Recur. Nat. 1985, 2, 312-330.

19. Ambec, S.; Cohen, M.A.; Elgie, S.; Lanoie, P. The Porter hypothesis at 20: Can environmental regulation enhance innovation and competitiveness? Rev. Environ. Econ. Policy 2013, 7, 2-22. [CrossRef] 
20. López-Gamero, M.D.; Molina-Azorín, J.F.; Claver-Cortés, E. The potential of environmental regulation to change managerial perception, environmental management, competitiveness and financial performance. J. Clean. Prod. 2010, 18, 963-974. [CrossRef]

21. Yuan, B.; Ren, S.; Chen, X. Can environmental regulation promote the coordinated development of economy and environment in China's manufacturing industry?-A panel data analysis of 28 sub-sectors. J. Clean. Prod. 2017, 149, 11-24. [CrossRef]

22. Mi, Z.; Zeng, G.; Xin, X.; Shang, Y.; Hai, J. The extension of the Porter hypothesis: Can the role of environmental regulation on economic development be affected by other dimensional regulations? J. Clean. Prod. 2018, 203, 933-942.

23. Shen, N.; Liao, H.; Deng, R.; Wang, Q. Different types of environmental regulations and the heterogeneous influence on the environmental total factor productivity: Empirical analysis of China's industry. J. Clean. Prod. 2019, 211, 171-184. [CrossRef]

24. Xing, X.; Liu, T.; Wang, J.; Shen, L.; Zhu, Y. Environmental regulation, environmental commitment, sustainability exploration/exploitation innovation, and firm sustainable development. Sustainability 2019, 11, 6001. [CrossRef]

25. Testa, F.; Iraldo, F.; Frey, M. The effect of environmental regulation on firms' competitive performance: The case of the building \& construction sector in some EU regions. J. Environ. Manage. 2011, 92, 2136-2144.

26. Castellacci, F.; Lie, C.M. A taxonomy of green innovators: Empirical evidence from South Korea. J. Clean. Prod. 2017, 143, 1036-1047. [CrossRef]

27. Zhou, X.; Feng, C. The impact of environmental regulation on fossil energy consumption in China: Direct and indirect effects. J. Clean. Prod. 2017, 142, 3174-3183. [CrossRef]

28. Liu, T.; Ren, Z.; Zhang, Y.; Feng, B.; Lin, H.; Xiao, J.; Zeng, W.; Li, X.; Li, Z.; Rutherford, S. Modification effects of population expansion, ageing, and adaptation on heat-related mortality risks under different climate change scenarios in Guangzhou, China. Int. J. Environ. Res. Public Health 2019, 16, 376. [CrossRef]

29. Del Río González, P. The empirical analysis of the determinants for environmental technological change: A research agenda. Ecol. Econ. 2009, 68, 861-878. [CrossRef]

30. Li, Z.F.; Thibodeau, C. CSR-Contingent executive compensation incentive and earnings management. Sustainability 2019, 11, 3421. [CrossRef]

31. Ikram, A.; Li, Z.F.; Minor, D. CSR-contingent executive compensation contracts. J. Bank. Financ. 2019. [CrossRef]

32. Song, H.; Zhao, C.; Zeng, J. Can environmental management improve financial performance: An empirical study of A-shares listed companies in China. J. Clean. Prod. 2017, 141, 1051-1056. [CrossRef]

33. Ramanathan, R.; He, Q.; Black, A.; Ghobadian, A.; Gallear, D. Environmental regulations, innovation and firm performance: A revisit of the Porter hypothesis. J. Clean. Prod. 2017, 155, 79-92. [CrossRef]

34. Sharma, S. Different strokes: Regulatory styles and environmental strategy in the North-American. Bus. Strateg. Environ. 2001, 10, 344-364. [CrossRef]

35. Ren, S.; Li, X.; Yuan, B.; Li, D.; Chen, X. The effects of three types of environmental regulation on eco-efficiency: A cross-region analysis in China. J. Clean. Prod. 2018, 173, 245-255. [CrossRef]

36. Teece, D.J.; Pisano, G.; Shuen, A. Dynamic capabilities and strategic management. Strateg. Manag. J. 1997, 18, 509-533. [CrossRef]

37. Kogut, B.; Zander, U. Knowledge of the firm, combinative capabilities, and the replication of technology. Organ. Sci. 1992, 3, 383-397. [CrossRef]

38. Dougherty, D. Interpretive barriers to successful product innovation in large firms. Organ. Sci. 1992, 3, 179-202. [CrossRef]

39. Helfat, C.E.; Raubitschek, R.S. Product sequencing: co-evolution of knowledge, capabilities and products. Strateg. Manag. J. 2000, 21, 961-979. [CrossRef]

40. Chen, Y.S.; Chang, C.H. The determinants of green product development performance: Green dynamic capabilities, green transformational leadership, and green creativity. J. Bus. Ethics 2013, 116, 107-119. [CrossRef]

41. Mousavi, S.; Bossink, B.; van Vliet, M. Dynamic capabilities and organizational routines for managing innovation towards sustainability. J. Clean. Prod. 2018, 203, 224-239. [CrossRef]

42. Brink, T. Orchestration of dynamic capabilities for competitive advantage. Int. J. Energy Sect. Manag. 2019, 13, 960-976. [CrossRef] 
43. Lin, Y.H.; Chen, Y.S. Determinants of green competitive advantage: the roles of green knowledge sharing, green dynamic capabilities, and green service innovation. Qual. Quant. 2017, 51, 1663-1685. [CrossRef]

44. Boons, F.; Montalvo, C.; Quist, J.; Wagner, M. Sustainable innovation, business models and economic performance: An overview. J. Clean. Prod. 2013, 45, 1-8. [CrossRef]

45. Rashid, N.; Jabar, J.; Yahya, S.; Shami, S. Dynamic eco innovation practices: A systematic review of state of the art and future direction for eco innovation study. Asian Soc. Sci. 2015, 11, 8-21. [CrossRef]

46. Delai, I.; Takahashi, S. Corporate sustainability in emerging markets: Insights from the practices reported by the Brazilian retailers. J. Clean. Prod. 2013, 47, 211-221. [CrossRef]

47. Maletič, M.; Maletič, D.; Dahlgaard, J.J.; Dahlgaard-Park, S.M.; Gomišček, B. Sustainability exploration and sustainability exploitation: From a literature review towards a conceptual framework. J. Clean. Prod. 2014, 79, 182-194. [CrossRef]

48. March, J.G. Exploration and exploitation in organizational learning. Organ. Sci. 1991, 2, 71-87. [CrossRef]

49. Maletič, M.; Maletič, D.; Dahlgaard, J.J.; Dahlgaard-Park, S.M.; Gomišček, B. Effect of sustainability-oriented innovation practices on the overall organisational performance: An empirical examination. Total Qual. Manag. Bus. Excell. 2016, 27, 1171-1190. [CrossRef]

50. Chang, C.H. The influence of corporate environmental ethics on competitive advantage: The mediation role of green innovation. J. Bus. Ethics 2011, 104, 361-370. [CrossRef]

51. Maletič, M.; Maletič, D.; Gomišček, B. The impact of sustainability exploration and sustainability exploitation practices on the organisational performance: a cross-country comparison. J. Clean. Prod. 2016, 138, 158-169. [CrossRef]

52. You, D.; Zhang, Y.; Yuan, B. Environmental regulation and firm eco-innovation: Evidence of moderating effects of fiscal decentralization and political competition from listed Chinese industrial companies. J. Clean. Prod. 2019, 207, 1072-1083. [CrossRef]

53. Zhao, X.; Sun, B. The influence of Chinese environmental regulation on corporation innovation and competitiveness. J. Clean. Prod. 2016, 112, 1528-1536. [CrossRef]

54. Xing, X.; Wang, J.; Tou, L. The relationship between green organization identity and corporate environmental performance: The mediating role of sustainability exploration and exploitation innovation. Int. J. Environ. Res. Public Health 2019, 16, 921. [CrossRef]

55. Xie, R.H.; Yuan, Y.J.; Huang, J.J. Different types of environmental regulations and heterogeneous influence on "green" productivity: Evidence from China. Ecol. Econ. 2017, 132, 104-112. [CrossRef]

56. Zhang, Y.; Wang, J.; Xue, Y.; Yang, J. Impact of environmental regulations on green technological innovative behavior: An empirical study in China. J. Clean. Prod. 2018, 188, 763-773. [CrossRef]

57. Zollo, M.; Winter, S.G. Deliberate learning and the evolution of dynamic capabilities. Organ. Sci. 2002, 13, 339-351. [CrossRef]

58. Eisenhardt, K.M.; Martin, J.A. Dynamic capabilities: What are they? Strateg. Manag. J. 2000, 21, 1105-1121. [CrossRef]

59. Artiach, T.; Lee, D.; Nelson, D.; Walker, J. The determinants of corporate sustainability performance. Account. Financ. 2010, 50, 31-51. [CrossRef]

60. Ameer, R.; Othman, R. Sustainability practices and corporate financial performance: A study based on the top global corporations. J. Bus. Ethics 2012, 108, 61-79. [CrossRef]

61. Wales, W.J.; Parida, V.; Patel, P.C. Owners on both sides of the deal: Mergers and acquisitions and overlapping institutional ownership. Strateg. Manag. J. 2013, 28, 1319-1350.

62. Oliveira Neto, G.C.; Leite, R.R.; Shibao, F.Y.; Lucato, W.C. Framework to overcome barriers in the implementation of cleaner production in small and medium-sized enterprises: Multiple case studies in Brazil. J. Clean. Prod. 2017, 142, 50-62. [CrossRef]

63. De Marchi, V. Environmental innovation and R\&D cooperation: Empirical evidence from Spanish manufacturing firms. Res. Policy 2012, 41, 614-623.

64. Adner, R.; Helfat, C.E. Corporate effects and dynamic managerial capabilities. Strateg. Manag. J. 2003, 24, 1011-1025. [CrossRef]

65. Chen, Y.S.; Lin, Y.H.; Lin, C.Y.; Chang, C.W. Enhancing green absorptive capacity, green dynamic capacities and green service innovation to improve firm performance: An analysis of Structural Equation Modeling (SEM). Sustainability 2015, 7, 15674-15692. [CrossRef] 
66. Zhou, Y.; Hong, J.; Zhu, K.; Yang, Y.; Zhao, D. Dynamic capability matters: Uncovering its fundamental role in decision making of environmental innovation. J. Clean. Prod. 2018, 177, 516-526. [CrossRef]

67. Jansen, J.J.P.; Van Den Bosch, F.A.J.; Volberda, H.W. Exploratory innovation, exploitative innovation, and performance: Effects of organizational antecedents and environmental moderators. Manage. Sci. 2006, 52, 1661-1674. [CrossRef]

68. Uotila, J.; Maula, M.; Keil, T.; Zahra, S.A. Exploration, exploitation, and financial performance: analysis of S\&P 500 corporations. Strateg. Manag. J. 2009, 30, 221-231.

69. Maletič, M.; Maletič, D.; Dahlgaard, J.J.; Dahlgaard-Park, S.M.; Gomišček, B. The Relationship between sustainability- oriented innovationpractices and organizational performance: empiricalevidence from slovenian organizations. Organizacija 2014, 47, 3-13. [CrossRef]

70. Tomšič, N.; Bojnec, Š.; Simčič, B. Corporate sustainability and economic performance in small and medium sized enterprises. J. Clean. Prod. 2015, 108, 603-612. [CrossRef]

71. Maletič, M.; Maletič, D.; Gomišček, B. The role of contingency factors on the relationship between sustainability practices and organizational performance. J. Clean. Prod. 2018, 171, 423-433. [CrossRef]

72. Jansen, J.J.P.; Van den Bosch, F.A.J.; Volberda, H.W. Exploratory innovation, exploitative innovation, and ambidexterity: The impact of environmental and organizational antecedents. Schmalenbach Bus. Rev. 2005, 57, 351-363. [CrossRef]

73. Aboelmaged, M. The drivers of sustainable manufacturing practices in Egyptian SMEs and their impact on competitive capabilities: A PLS-SEM model. J. Clean. Prod. 2018, 175, 207-221. [CrossRef]

74. Podsakoff, P.M.; MacKenzie, S.B.; Lee, J.Y.; Podsakoff, N.P. Common method biases in behavioral research: A critical review of the literature and recommended remedies. J. Appl. Psychol. 2003, 88, 879-903. [CrossRef]

75. Weng, H.H.R.; Chen, J.S.; Chen, P.C. Effects of green innovation on environmental and corporate performance: A stakeholder perspective. Sustainability 2015, 7, 4997-5026. [CrossRef]

76. Cohen, M.A.; Tubb, A. The impact of environmental regulation on firm and country competitiveness: A meta-analysis of the porter hypothesis. J. Assoc. Environ. Resour. Econ. 2018, 5, 371-399. [CrossRef]

77. Eiadat, Y.; Kelly, A.; Roche, F.; Eyadat, H. Green and competitive? An empirical test of the mediating role of environmental innovation strategy. J. World Bus. 2008, 43, 131-145. [CrossRef]

78. Li, F. Endogeneity in CEO power: A survey and experiment. Invest. Anal. J. 2016, 45, 149-162. [CrossRef]

79. Wang, H.; Lu, W.; Ye, M.; Chau, K.W.; Zhang, X. The curvilinear relationship between corporate social performance and corporate financial performance: Evidence from the international construction industry. J. Clean. Prod. 2016, 137, 1313-1322. [CrossRef]

80. Voss, G.B.; Voss, Z.G. Strategic ambidexterity in small and medium-sized enterprises: Implementing exploration and exploitation in product and market domains. Organ. Sci. 2013, 24, 1459-1477. [CrossRef]

81. Vanpoucke, E.; Vereecke, A.; Wetzels, M. Developing supplier integration capabilities for sustainable competitive advantage: A dynamic capabilities approach. J. Oper. Manag. 2014, 32, 446-461. [CrossRef]

82. Martinez-Conesa, I.; Soto-Acosta, P.; Palacios-Manzano, M. Corporate social responsibility and its effect on innovation and firm performance: An empirical research in SMEs. J. Clean. Prod. 2017, 142, 2374-2383. [CrossRef]

83. Fornell, C.; Larcker, D.F. Evaluating structural equation models with unobservable variables and measurement error. J. Mark. Res. 1981, 18, 39-50. [CrossRef]

84. Ağan, Y.; Kuzey, C.; Acar, M.F.; Açikgöz, A. The relationships between corporate social responsibility, environmental supplier development, and firm performance. J. Clean. Prod. 2016, 112, 1872-1881. [CrossRef]

85. Hu, D.; Wang, Y.; Huang, J.; Huang, H. How do different innovation forms mediate the relationship between environmental regulation and performance? J. Clean. Prod. 2017, 161, 466-476. [CrossRef]

86. Sheng, J.; Zhou, W.; Zhang, S. The role of the intensity of environmental regulation and corruption in the employment of manufacturing enterprises: Evidence from China. J. Clean. Prod. 2019, 219, $244-257$. [CrossRef]

87. Rubashkina, Y.; Galeotti, M.; Verdolini, E. Environmental regulation and competitiveness: Empirical evidence on the Porter Hypothesis from European manufacturing sectors. Energ Policy 2015, 83, 288-300. [CrossRef]

88. Yu, W.; Ramanathan, R.; Nath, P. Environmental pressures and performance: An analysis of the roles of environmental innovation strategy and marketing capability. Technol. Forecast. Soc. Change 2017, 117, 160-169. [CrossRef] 
89. Yuan, B.; Ren, S.; Chen, X. Can environmental regulation promote the coordinated development of economy and environment in China's manufacturing industry?-A panel data analysis of 28 sub-sectors. J. Clean. Prod. 2017, 149, 11-24. [CrossRef]

90. Zhao, X.; Zhao, Y.; Zeng, S.; Zhang, S. Corporate behavior and competitiveness: Impact of environmental regulation on Chinese firms. J. Clean. Prod. 2015, 86, 311-322. [CrossRef]

91. Collins, E.; Lawrence, S.; Pavlovich, K.; Ryan, C. Business networks and the uptake of sustainability practices: the case of New Zealand. J. Clean. Prod. 2007, 15, 729-740. [CrossRef]

92. Wolf, J. The relationship between sustainable supply chain management, stakeholder pressure and corporate sustainability performance. J. Bus. Ethics 2014, 119, 317-328. [CrossRef]

(C) 2020 by the authors. Licensee MDPI, Basel, Switzerland. This article is an open access article distributed under the terms and conditions of the Creative Commons Attribution (CC BY) license (http://creativecommons.org/licenses/by/4.0/). 